\title{
The Trajectories of Theological and Religious Studies in Western Academies: Basis for Customized Programmes at NUL and in some other African Higher Theological Institutions in Contemporary Times
}

\author{
Dr. Nico Tebatso Makhalemele ${ }^{1}$, Chris Ukachukwu Manus ${ }^{2}$ \\ ${ }^{1}$ Department of Theology \& Religious Studies, Faculty of Humanities, National University of Lesotho, \\ P.O. Roma 180, Lesotho, Southern Africa. \\ ${ }^{2}$ Professor, Department of Theology \& Religious Studies, Faculty of Humanities, National University of Lesotho, \\ P.O. Roma 180, Lesotho, Southern Africa.
}

\begin{abstract}
This paper is a descriptive account of the courses theological and Religious Studies education have undertaken in institutions of Higher Education (HE) since the Aufklarung; namely since the period of the Enlightenment in Europe. The trajectories are briefly traced from German scholarship and some other European great minds that migrated to the USA during WW II. Mention is made of the famous scholars whose findings had, until recently, inspired and influenced African scholars' praxes in the African academies. Based on the increasing scientific acceptance that contexts determine the theologizing one does, our paper delineates the efforts that have been undertaken in some African academies to customize the borrowed approaches in the bid to address socio-political and health-care issues in Africa. Examples of some African HE curricula on TRS are sampled, their philosophies, visions and objectives displayed and commented upon. The inherent values derived from adaptations of Western approaches by African scholars are discussed. But preference is shown towards the use of African critical resources to give reins to the aims and objectives so that African specific issues such as HIV/AIDS that are endemic in the African contexts are mainstreamed. The paper concludes, inter alia, on a stern note that some basic infrastructural facilities are pertinent to prosper the development of skills for teaching and learning by committed Theological and Religious Studies staff in African institutions of Higher Education today.
\end{abstract}

Keywords: Science of Religion, Contextual theology, Mysticism, Supernaturalism, Theological phenomenology, HIV/AIDS prevalence, Brahmins, Schism.

\section{Introduction}

We wish to address our topic with a methodology with which we trace the tortious courses or journeys through which the sciences of theology and religion had moved till its soft landing in some of the African academies of the twenty-first century. The choice is, of course, selective. Hence, some apparently topical issues such as the exploration of the foundational history of individual Seminaries, Theological Colleges and Universities where these sciences had long been established shall be left out. While we acknowledge the significance and relevance of Philosophy as Ancilla Theologiae (Maid-Servant of Theology); recent developments in the studies of Sociology and Anthropology as new-born babies of Theology and Religious Studies as well as the contemporary emergence of activist movements like Liberation Theology, Black Theology, Feminist Theology and Contextual Theology generally derived from the spirit and letters of religious and sacred literatures of major world religions are not included in this presentation. Rather, we have adjudged the historical survey to be most deserving of attention in this kind of research, however brief and scanty our paper may be. Indeed, there is scarce resources available to us where we work to empower us to launch an apologia pro studium religionum; that is, apology for the study of Theology and Religions in African colleges and universities; especially now that industries, technocrats and canvassers in the labour markets have began to appreciate the values and relevance of the humanistic and ethical components in the total package for the education and the employability of the human person; the graduates from our disciplines.

\section{The Trajectories: A Brief Historical Survey}

The founders of the Religionsgeschichtliche Schule, (German: History of Religions School) who promoted the concept Religionswissenschaft, (Science of Religion) in most Continental European Institutions of Theological and Religious studies had long adopted the comparative and the historical methods of research in their studies. The Religionsgeschichtliche Schule which was firstly developed from German biblical scholarship during the nineteenth century had emphasized the degree to which biblical ideas and motifs had to be accepted as the product of a cultural milieu. Important in this line of thought and development was Albert Schweitzer (1875-1965). In his famous work, The Quest of the Historical Jesus (1906)[1], he had presented a critical response on the so-called "launched" quest for the historicity of Jesus, the Jew from Galilee. For Schweitzer, in seeking the "real" Jesus, New Testament scholars had ended up constructing a totally unhistorical Jesus to fit their own philosophical and religious presuppositions. Summarizing Schweitzeres scientific argumentation on the so-called quest, R.B. Strimple had this to say: "They had found a Jesus who looked more like a 


\section{International Journal of Science and Research (IJSR) \\ ISSN (Online): 2319-7064 \\ Index Copernicus Value (2013): 6.14 | Impact Factor (2014): 5.611}

deist, a follower of Hegel, or a protestant liberal than the actual Jesus of history"[2] One of the most brilliant and unforgettable New Testament critical scholars who defended the scientific approach in the study of Theology and Religions was Rudolf Bultmann, the New Testament scholar and theologian from the University of Marburg. Besides, to show how Religion and Philosophy go hand in hand, that is, to define the factum that philosophia (est) ancilla theologia: that philosophy indeed remains the maidservant of religion, Bultmann made use of Heidegger's concept of Dasein and his ontological review of hermeneutics to interpret "the meaning of faith as a possible mode of human being"[3]. Christian faith, according to Bultmann," is a decision the Self as Dasein makes to entrust itself to the grace of God that breaks into the world through the kerygma of the New Testament" [Ibid].

For Bultmann, the Methodology of Form Criticism on the New Testament was the benchmark for the study of Biblical Religion. In the light of their post-Enlightenment culture and thought-form, it must be stressed that Bultmann was grossly influenced by the ideas of Soeren Aabye Kierkegaard (18131855) the Danish first existentialist philosopher (and a philosopher of religion) and the German existentialist philosopher, Martin Heidegger (1889-1976). Since existentialism had emphasized, among other things, personal experience and understanding, the very scientific objective of Bultmann's thesis was one roundly captured in his book, The New Testament and Mythology and Other Basic Writings, [4] on account of which Robert B. Strimple, now, Professor Emeritus of Systematic Theology at Westminster Seminary, California had, in support, stated that "the cosmology of the New Testament is essentially mythical in character" [5].

According to Strimple, Bultmann had further asserted that: What must be done, is not to delete but to transform that

Kerygma into a conceptual framework with which the modern

People operate ...(rather) we must understand New Testament

Methodology not cosmologically but

anthropologically,

Or more specifically, existentially.[6]

In his bid to be truly scientific in biblical studies, Rudolf Bultmann discountenanced the supernatural components of the gospel stories and those others of the New Testament as a whole. He went as far as to reject the miraculous and recommended a separation of "Jesus of history" from the "Christ of faith" which he concluded was the making of the early church. It was Bultmann who promoted the thesis that the gospels must be "demythologized"; namely that the relevant kernel of the gospels, according to him, needs to be extracted from the "out-moded" husks of primitive supernaturalism, including the miraculous and the exorcisms. Insisting that the New Testament worldview was mythical and pre-scientific, Bultmann asserted:

It is impossible to use electric-light and the wireless and to avail us of modern medical and surgical discoveries and at the same time believe in the New Testament world of demons and spirits. We may think we can manage it in our own lives, but to expect others to do so, is to make the Christian faith unintelligible and unacceptable to the modern world [7].

Thus far, scholars before our era who had been influenced by the History of Religions Approach in the Study of Theology and Religion had generally understood the disciplines ${ }^{\text {ee }}$ method as non-normative, that is to say, that its School of Thought had attempted to delineate facts, whether historical or structural, without judging them from a Christian or other faith viewpoints. That was indeed the beginning of the objective study of Theology and Religions which had infuriated and agitated the scholar churchmen who had held themselves as servants of the church engaged in the elucidation of the canonical Christian scriptures. Today, it annoys bible fundamentalists and many evangelicals; especially their kinds in Africa who take it for granted that every word or every account in the Gospels are the ipsissima verba Jesu: the very words of Jesus.

But the modern History of Religions reached its apogee during the time of Max Muller (1856-1900) who performed as the real founder of comparative religions as he declared it a formal and independent field of study that today passes no judgmental sentence on the truth claims of religions. However, in the latter part of the nineteenth century, an attempt was made to place the methodology of comparative religion and mythology on a systematic or methodical basis. During this period, various lectureships and professorial chairs were instituted in the Universities in Western Europe and the United States on the discipline. The first congress of Religionswissenschaft took place in Stockholm in 1897, and a similar one on the History of Religions was held at Paris in 1900. Later, the International Association for the History of Religions (IAHR) was born and one of its latest Congresses was held in August 2011 at the University of Toronto, Canada. Various National Associations including some in African Universities have sprung up since then and are affiliates.

An avalanche of scholarly works in the field had been devoted to the exploration of particular Religious and Theological histories, piecing together, for instance, the History of Gnosticism or that of early Buddhism. Within that historical trajectory, Christianity was studied from the same point of view until recently when much significant works have begun to adopt the comparative and structural approaches. This had ranged from the attempt to establish particular comparisons, such as that initiated by Rudolf Otto $\mathrm{s}$ comparison; especially in his study [8] that hinged so much on the thoughts of Meister Eckehart (1260-1328), natively called Eckhart von Hochheim, a medieval German theologian, philosopher and mystic who had worked among pious groups known as The Friends of God. Eckhart belonged to the medieval scholastic and theological tradition that drew much from the original ideas of the Hindu philosopher and theologian, Adi Śankara, born mid $8^{\text {th }}$ century of the Common Era (CE), who had expounded the Advaita Vedanta doctrines and thereby promoted the unification of the main configurations of thought in Hinduism. Both thinkers furnished the ideas that gave vent towards a systematic typology that later became crystallized into the thoughts of Gerardus van der Leeuw, the early mid-

\section{Volume 4 Issue 12, December 2015}




\section{International Journal of Science and Research (IJSR) \\ ISSN (Online): 2319-7064 \\ Index Copernicus Value (2013): 6.14 | Impact Factor (2014): 5.611}

$20^{\text {th }}$ century Dutch scholar who had applied the methods of theological phenomenology in the study of Religion. Van der Leeuw promoted the quest for the difference between Religion and Theology. In his tall work:[9], amongst others, he made the earliest attempt to establish the science of Religion as a cultural and historical practice. He also spread the idea of studying religious practices from the perspective of the long-standing theological studies in order to critique the relevance of each religion and its practices.[10].

At the close of the nineteenth and the beginning of the twentieth century, and with the emergence of Departments of Religion in the United States public universities; Religious Studies had become acknowledged as a men's club led by few great intellectuals. Since then, the Science of Religion had grown wings so much so that there have emerged so many significant scholars in the discipline welling up to the emergence of the bright ideas of Friedrich Max Müller (1823-1900), the pioneer in the areas of Vedic Studies, Comparative Philosophy, Mythology and Comparative Religion at Oxford. His theories are evidenced in his works; especially [11].

In fact, the trajectories had reached their summit in the 20th century when Rudolf Otto (1869-1937) had inaugurated a profound impression on the scholarly world with the publication of his [12]. The Idea of the Holy (nota bene: its original German edition appeared in 1917) in which he had delineated the centrality of human experience and sentiment in the religious sphere. He further elucidated the concept of the Holy which many contemporary African scholars are still addicted to parodying in their courses and lectures. In the North American scenario, was it not the GermanAmerican Historian of Religions, Joachim Wach (18981955) who had established the German traditional Religionswissenschaft at the University of Chicago. Was he not the founder of the modern "Chicago School"? It is well known by our forerunners in this "Science" that Wach was concerned with emphasizing three aspects of religion: the theoretical or the mental; that is, the study about religious ideas and images, the practical or the behavioral, and the institutional or the social aspects of Religion. And because of this "Godfathere"s" concern for the critical study of religious experience, Wach promptly laid the foundation for the Sociology of Religion, through which he attempted to indicate how religious values had shaped the institutions that had founded and transmitted them.

In the twentieth century, Mircea Eliade (1907-1986), a Romanian born scholar who had migrated to the United States after World War I came to the scene. He had exercised a wide influence on later thinkers, partly because of his substantive studies on Yoga and Shamanism and partly because of his later writings in which he had attempted to synthesize data from a wide variety of world cultures3 [14 ] The synthesis incorporated a theory of myth and history. Two important elements in the theory of Eliade that have continued to boost the science of Theology and Religion in African theological education to date are: first, that the distinction between the sacred and the profane is fundamental to theological and religious thinking and is to be interpreted existentially; that is to say, the symbols of religion are, typically profane in literal interpretation but are of cosmic significance when viewed as signs of the sacred; and, second, that archaic religion is to be contrasted with the linear, historical view of the world. The latter essentially comes from biblical religion. In his thought, the former viewpoint tends to treat time cyclically and mythically, referring to foundational events such as creation, the beginning of the human race, and the Fall of man on a cycle towards the illud tempus (the sacred primordial time) that is re-enacted in the repetitions of the ritual and in the retelling of the myth.

How about the developments in the exegesis of the canonical scriptures of the Christian Religion? The Supreme Court in the US in its Establishment Clause (1963), had decreed that the objective teaching and learning of Religion be allowed in American Public Schools. Thereafter, in the 60s and the 70s, many American state Universities began to establish Departments of Religious Studies. Biblical Studies exploded from the Seminaries, acquired pluralistic interests and got sub-divided into many approaches and methodologies from the perspectives of cognate sciences [15].The new age approaches are evidenced in J.H. Hays work [16]. It is well known that the social contexts of the Humanities in many American Universities brought about novel approaches that had penetrated African higher institutions of Religious and Theological Studies so much so that many Africans, men and women have begun to take critical interests in biblical science for researches on liberation, contextualization and contextual hermeneutics.

\section{Implications of the Trajectories for Curricula Revision in African Higher Institutions}

Given these insights, need we raise any more the question as to what Theological and Religious Studies have to offer African students and researchers in the academy? Since African theologians and Religion scholars in recognition of the significance of social location for theological interpretations African make, and are unanimously agreed that African "history is both sacred and secular"; the trajectories briefly traced above compel us to re-emphasize our earlier verdict that both Theological and Religious Studies are and must be seen as inter-disciplinary studies that ask enduring questions about religion, African societies, and the meaning Africans and their communities make in life. Besides the studies help promote humankind's awareness of his or her environment which African academies must be in the frontline of the quest. Narrowed down to African peoples immediate needs in todayes world, the trajectories inspire African scholars to begin to think critically about religions in interaction with other cultural, historical, intellectual and social phenomena in the African continent now plagued by religious radicalism and geopolitical crises that lead to recurrent militancy and insurgencies as a non-African commentator has observed.[17].

Consequent upon the classical thoughts of the "ancestors" or our "forebears" in the disciplines, we wish to concede that Theology and Religious Studies as the academic fields of a multi-disciplinary, secular study of religious beliefs,

\section{Volume 4 Issue 12, December 2015}




\section{International Journal of Science and Research (IJSR) \\ ISSN (Online): 2319-7064}

Index Copernicus Value (2013): 6.14 | Impact Factor (2014): 5.611

behaviours, and institutions there is urgent need for review. As academic fields of study, and as both disciplines are scientifically concerned with the critical and analytical descriptive, comparative, interpretative and the elucidation of religions as human phenomena; especially to unravel the truth claims of theological and religious beliefs, practices, experiences, institutions and the behavior of religious and faith people, the review is one that beckons for our attention. Through the various approaches scholars had bordered themselves with the interpretation and description of how religion and theological ideas shape human societies and vivify the moral and ethical lives of individuals has become a plus in the role of the humanities today. In that case, theology and religion must be studied as "human phenomena" to facilitate the appreciation of the presence of other religions and not as a faith or credo [18]. M. Eliade had correctly demonstrated that the science of religion clarifies the differences between the sacred and the profane.

\section{African Contexts and the Need for Theological-Religious Studies Education}

Admittedly since context determines the teaching, the research and the interpretation scholars produce in the academy, the African situation and the lives of our various peoples require African theological and religious studies programmes to invent and design approaches that address the African contexts. In the Sub-Saharan African countries the HIV/AIDS pandemic is so widespread; especially in the southern Africa sub-region. This was amply demonstrated on $1^{\text {st }}$ December, 2015 World's AIDS Day. This rising rate of infections calls for urgent review of programmes that need to be put in place to checkmate the spread among staff and students. Prof. Joseph Omoregbe, one-time Professor at the National University of Lesotho (NUL), informs us that "There are approximately six million people infected with the virus and living with it in South Africa. Swaziland, with over $26 \%$ of its population infected with the virus has the highest percentage of HIV/AIDS prevalence in the world, followed by Botswana with over $23 \%$ of the population living with the virus [19]. Theological and Religious Studies Programmes have taken very aggressive and sympathetic interest in mainstreaming courses on Religion, Gender and HIV/AIDS and Pastoral Care and Counselling. The devastating pandemic needs to be tackled from all fronts. Theology and Religion cannot shy away from the battle; after all, scriptural, religious and theological arguments have often been used to vilify the infected. Kenyata University in Nairobi, Kenya, for example, had launched a pro-active programme on Counselling for People Living with HIV/AIDS. The Dept. of Religious Studies had been offering courses tailored to make students and staff come to a full awareness of the need to reduce and eliminate the spread of the awful pandemic in the University and in the larger Kenyan society. The Catholic University of Eastern Africa (CUEA), Nairobi, was one of the earliest faith-based Tertiary institutions to provide a Pastoral Theological counselling and Care Services education that have been integrated into programmes for students and staff on the problems posed by the pandemic in that touristic nation of Eastern Africa.

\section{The Example of the National University of Lesotho (NUL), Roma.}

In the National University of Lesotho (NUL), Roma, where both of us work, serious public address-system campaigns are used to alert members of the Estate from time to time of the existence of HIV/AIDS on campus and its environs. Mind bogging slogans are posted on bill-boards to warn students and staff of the devastating effects of the pandemic on human life. For a small southern African nation as Lesotho with 2.8 million people, its over $20 \%$ rate of infection is really on a high side .[21] The University"s leadership is seriously committed to the directives of African Universities to brace up for the challenges being posed by the epidemic. The University campaigns include the mounting of a number of bill-boards to open the eyes and ears of the students and staff to be extra-vigilant when they engage in careless behaviours. One singular slogan boldly reads: "Graduate with "A"s and not with "AIDS". The advert captures it all as it speaks volume. A $21^{\text {st }}$ century organization, the Global Fund Support Program, the recipient of funds from philanthropic organizations in its effort to accelerate the reduction of HIV/AIDS has provided the University with boxes with the information Zero (Tolerance to) New Infections and also written in Sesotho: PHELISO EA TSO' AETSO E NCHA mounted in the rest rooms of hostels, toilet rooms of Faculties and closets stuffed with condoms for use by both males and females. The underlying reason is to warn students and staff who might have already been infected to use the condoms to mitigate further re-infections as types or strains differ from stronger to weaker persons.

In the past week; especially as the National University of Lesotho Sports Association (NULSA) as part of the concluding event of the University's proud celebration of its $70^{\text {th }}$ Anniversary of "creating champions 1945-2015" hosted the $16^{\text {th }}$ Southern African Universities Staff Sports Association (SAUSSA) Tournament from the $14^{\text {th }}$ to the $20^{\text {th }}$ of December, 2015 at NUL, Roma Campus, a notable advertorial to all the visitors stated: National University of Lesotho, AIDS Program: "Getting to Zero: Improving Access to Prevention, Treatment and Care Services to Adolescents". With this sort of advert, the University management showcased its pragmatic effort to harmer out the voice of the authority to keep all who live and vist the Campus on red-alert for the prevailing and continuing dangers of the HIV pandemic. The Department of Theology and Religious Studies has been striving to key into the university $\mathrm{s}$ programme to checkmate the incursion of the pandemic. It offers courses like: T101-3: Human Sexuality and HIV/AIDS; T120 - 3: HIV/AIDS Pandemic and Humankind's Survival, T130-3: Theology of Suffering and Death; T213-3: Theology of Pastoral Care and Counselling;T224-3: Marriage and Family, T302-3: Religious Response to HIV/AIDS Pandemic; T413-3: Gender Issues and Morality; T417-3: Counselling Theories, T424-3: Turning Crisis into an Opportunity and as shown above, the mounting of courses on Pastoral Care and Counselling complemented with instructive fieldwork and extension Practicum in the Basotho society are all aimed at promoting "a healthier, happier and longer life". [22] 


\section{International Journal of Science and Research (IJSR) \\ ISSN (Online): 2319-7064}

Index Copernicus Value (2013): 6.14 | Impact Factor (2014): 5.611

At the University of Botswana, Prof Musa W. Dube had championed a massive re-education of the students and staff through her engaged courses, lectures and publications on the pandemic. Her edited work, 10 among others, represents an eloquent exemplary stride in an African academy to combat the tide of HIV/AIDS and to provide "a pattern of Christian education designed to equip churches for ministry in a time of crisis" through contextual Theological and Religious Studies education.[23]

\section{Customized Programmes in Some Other African Academies}

The philosophies, visions and objectives in the Handbooks of most tertiary institutions for the scientific study of Theology and Religion in Africa have been patterned on the tradition of the German and the Chicago Schools. To date, their ideas, methods and scope are replicated in most African Universities curricula. In most of the Faculties ${ }^{\text {ee }}$ handbooks, it is clearly indicated that the "objective study" of Theology and Religion aims:

(i) to understand the general features of religion as a social phenomenon and to acquaint students with the main contents of the major religions in Africa; namely Traditional Religion, Christianity and Islam.

(ii) to provide an understanding of critical skills about the theological implications of religion in human society, particularly on how religion affects relationships across cultures, ethnic communities, and in global contexts.

(iii) to appraise the historical, theological and ethical dimensions of religion in the modern world, as well as the engagement of theology and religion with other disciplines.

(iv) to equip our graduates with the moral and ethical foundation/basis for launching into other disciplines and professions such as Policy Analysis, (Socio-theological Criticism), Public Administration, Religion and Media, Social Work, Pastoral Care and Counselling and Religion and international Relations.[24]

As the facts stand, for example, at Obafemi Awolowo University, Ile-Ife, Nigeria, the scholars in its Department of Religious Studies strictly identify with the objectives and systematic approaches defined for the study of Religions. At the University of Legon, Accra, Ghana, the Department of Religions trains students to acquire the interpretative and scientific skills required for the analysis of the content of various religions and their literatures or Holy Books; especially as the Religions manifest themselves in Ghana and its neighbourhoods. From these two examples, academic theological and religious studies have, in view of the changing social location of scholars, students and the pluralistic spread of the English language, have become highly secularized. Imo State University, one of the new generation tertiary institutions in southeastern Nigeria, mainstreams Religious and Theological Studies Programmes with a bold-face philosophy that states that:

Religious Studies course is run on the understanding that the religious factor in man and society, like the other actors is very important. For a proper explication of man and his society, the religious factor has to be studied and its impacts delineated. Religion here is given purely academic and scientific touch. No one religious tradition is presented sui generis as an exclusivist system but as an aspect of human behaviour in society. An interdisciplinary and polymethodical approach is adopted to broaden the scope and purview of the students.

The programme sees in the different religious traditions, good human values, morals and ways of action which society should embrace for the good of all. In pursuance of national interest, the programme provides an academic insight into the major religious traditions in Nigeria with a view of creating a sense of religious freedom, understanding and openness in the citizenry and ensuring religious harmony and peaceful co-existence in a pluralistic society like Nigeria [25]

Besides its philosophy, that University (IMSU) has the following pertinently articulated objectives which are, in no way, dissimilar to the philosophy of world class Theological and Religious Studies Programmes. The aims are:

(a) to expose the students to the contents of the major religious traditions in Nigeria and the world

(b) to enable students see the impact of religion on the other sectors of society like political, economic, social, cultural and environmental issues and vice versa

(c) to place the students in a better position to make sharp objective and critical deductions on national and theoreligious issues

(d) to enable students apply their knowledge usefully in their personal and communal life and thereby ensure greater societal development

In this light, it is emphasized that the Programmes are not intended to produce religious ministers as the University is not a Seminary but that their products shall be well-equipped with the skills that can enable them to initiate inter-religious dialogues and to be able to engage in ecumenical discourse and carry out theological researches and assignments relevant for the spiritual satisfaction of African faith communities.

\section{Conclusion}

At this juncture, it can be asserted that what scholars in Theological and Religious Studies do, that other practitioners of other disciplines in the Humanities are not doing, is that persons trained in the academic study of Religion and Theology are fully sensitized so much so they have become highly appreciated and sought after by any career hunters who seek graduates that have become exposed to human cultures that can humanize the work force. Theology and Religious studies transmit such inherent values and the skill to relate to the metaphysical questions concerning human life which, in the modern world discourse, do provide the framework for any meaningful debate about the aims of development and how to understand and measure progress or the nature of the ,good life ${ }^{\mathrm{eo}}$ in a civilized human society.[26]

The worldviews and cosmologies of Africans with dominant beliefs in the plurality of divinities, spirit-entities and in

\section{Volume 4 Issue 12, December 2015}




\section{International Journal of Science and Research (IJSR) \\ ISSN (Online): 2319-7064}

Index Copernicus Value (2013): 6.14 | Impact Factor (2014): 5.611

impersonal mystical forces in nature remain potential indexes to measure the religious inclinations of the African humankind. It is well known that in Africa; especially in Lesotho, while the cult of Balimo (ancestors) is strongly believed in, the Great Spirit, Molimo, is widely acclaimed as the Supreme Being. Like elsewhere in Africa, West or East, religion is at the forefront of the peoplese esteemed and most cherished traditions, values, cultures and worldviews. Are the products of Theological and Religious Studies all over the globe not being provided with the opportunity to advance further into education for the evangelical, pastoral and ministerial leadership of faith communities? Certainly they are as it was the Brahmins who held upper-hand in Vedic Hinduism of old. At National University of Lesotho (NUL), the Pastoral Care and Counseing (PCC) programme in the Department of Theology and Religious Studies attracts the interest of many undergraduates so much so that a vast number of new entrants enroll massively into the Programme. We want to believe that the scientific study of Theology and Religion may therefore further enhance the theological education for persons (men and women) who are already in the service of a faith community or a religious group or denomination as professionally trained Pastors and Priests qualified to deliver the spiritual needs of the people. This is because Theological and Religious Studies had long recognized the need to emphasize both the scientific and the comparative studies of religions to objectify their commonalities. The Comparative Approach had been adopted to study the three Abrahamic religious traditions: Judaism, Christianity, Islam alongside African Traditional Religion. It has also indicated the active engagement of African scholars in the social cultural critiques of varying degrees of religious proliferations and their manifestations in contemporary African societies.

The central vision of our discussion confirms the popular slogan that Religion "smells" and "allures" people everywhere in contemporary Africa. We agree, otherwise how may one explain why hundreds of incurable faith persons in their droves fly to Prophet T. B. Joshuaes Synagogue in Lagos, Nigeria as well as those from South Africa who had to waste their lives during the collapse of the church in 2013? Is that how God has called them back to him? Has the philosophical study of Religion nothing critical to say on that incident? Can scholars of Theological and Religious Studies not address themselves to current African political leadership and their styles of democracy? What of the many and varied socio-religious challenges confronting the African countries today? What are the theological thinking and reflections that can promote viable national developments? Can TRS scholars not engage meaningfully in critiquing the rationale for the Transformation Agendas of many African sit-tight presidents? Does it not belong to mettle of scholars of TRS to critically discuss, for example, why the Roman Catholics in Ahiara Catholic Diocese in Mbaise, Imo State, Nigeria, flatly rejected the appointment of a Bishop by Rome and would not allow him to settle for work even after his consecration? Is that not a schism in the Church?

Let us not fail to recall that our enterprise involves us to pontificate in the prophetic tradition in both the sacred and the profane; namely "where vexing social religious and economic questions" prevail. As Theological and Religious Studies train students through the academic contents of various course-titles, it endeavors to prepare minds on a wider spectrum adjudged conducive to living in pluralistic societies like those of Africa. Thereupon the products are surely being empowered to intervene in the unholy wedlock between religion and politics in order as Gerrie Ter Haar advocates "to re-integrate both the spiritual power with the material power given the failure of modern conception of power to bring the two realms (material power and spiritual power) together".[27]

Finally to assist in the development of sensitive curricula through the study of Theology and Religion in Africa and to make them successfully thrive in African contexts; especially in the South African Sub-Region, some basic requirements are expected from the universities ${ }^{\text {ce }}$ management. Institutions where Theological and Religious Studies are established and offer courses; throughputs must be let to advance its Teaching and Learning Sciences and Policies such that:

(a) The Departments should own respectable libraries where books and literature specific to the study of theology and religions are stocked

(b) Staffing deficiencies must be addressed and promptly remedied. Positions for Graduate Assistants need to be established. The Institutions need aggressive employment policies in spite of some Governmental bureaucracies and over-ruling.

(c) Inadequate physical development and infrastructure should be provided for the smooth movement of staff and students.

(d) Staff morale must always be boosted so that they can expend their best to mentor and guide the students.

(e) There is need for Departmental Accreditation Committees charged with the responsibility to review the curricula in tune with present day realities confronting the African nations such as religious fundamentalism and bigotry; the Boko Haram, Al-Shabaab and the ISIS types.

(f) Funding should be increased to the Departments to be able to carry out their oversight functions and other innumerable tasks. It is here we rest our case.

\section{References}

[1] Albert Schweitzer, The Quest of the Historical Jesus: A Critical Study of Its Progress from Reimarus to Wrede, Tubingen, J.C.B. Mohr, 1906; ET. By W. Mongomery. London. A\&C Black, 1910.

[2] R. B. Strimple, The Modern Search for the Real Jesus, P \& R Publishers, New Jersey, 1995, p. 79.

[3] D. A; Knight, Methods of Biblical Interpretation, Nashville, Abingdon Press, 2004, p. 150.

[4] Cf. R. Bultmann's two volume-work where he had exemplified his theory: Introduction to the Old Testament, Vols. 1 \& 2, ET. London, SCM Press, 1970.

[5] Text quoted in J. D. Gwamna, "What do people say that I am?" Interrogating Current Trends in New Testament Studies", African Journal of Biblical Stusies, XXVII, 2, 2009, pp. 1-16, p.6.

[6] C. U. Manus "The Relevance of Religious Studies in Nigerian Universities Today", In Babalola, E.O, African

\section{Volume 4 Issue 12, December 2015}




\section{International Journal of Science and Research (IJSR) \\ ISSN (Online): 2319-7064}

Index Copernicus Value (2013): 6.14 | Impact Factor (2014): 5.611

Cultural Revolution, Islam \& Christianity in Yorubaland, Lagos, Eternal Communications, 2002, pp. 34-40; also as "The Relevance of Religious Studies in the Nigerian Universities, in Orita: Ibadan Journal of Religious Studies, 2009.

[7] Strimple, p. 120.

[8] Rudolf Otto, Mysticism East and West: A Comparative Analysis of the Nature of Mystery, Quest Books, Repr. 1987.

[9] G.van der Leeuw, Religion in Essence and Manifestation, 1933, 2 Vols. ET. 1983.

[10] Cf. http://al.as.ua.edu/a; retrieved 02.12.2015

[11] Max Muller, Introduction to the Science of Religion, Oxford, 1873.

[12] Strimple, p. 147.

[13] Bultmann, Works cited.

[14]M. Eliade, The Sacred and the Profane: The Nature of Religion; ET Willard R. Trask, Harper Torchbooks, New York, 1961; idem; Patterns of Comparative Religion, Sheed \& Ward, New York, 1958.

[15] Charles H. Cosgrove, Ä History of New Testament Studies in the $20^{\mathrm{th}}$ Cenntury", Review and Expositor 96, 1999, 369-383; 369-370.

[16] J.H. Hays (ed.), Dictionary of Biblical Interpretation, Abingdon Press, 1999 later excerpted as Methods of Biblical Interpretation, Abingdon Press, 2004, with Forward by Douglas A. Knight.

[17] John A. Hardon, Religions of the World, 1963, p. 7.

[18]NA, Obafemi Awolowo University, Ile-Ife, Nigeria, Faculty of Arts, Department of Religious Studies, 2012 Handbook, Religion as an Academic Discipline, p. 1.

[19] Obioma Des Obi, Imo State University, Owerri, Nigeria, 2012, Handbook of the Department of Religious Studies Students, pp. 1-2.

[20] Ibid.,

[21] J. I. Omoregbe, Let Us Go Back to God and Obey Him, Dept. of Theology and Religious Studies, National University of Lesotho, Print-Corp, 2010, p. 13

[22] The National University of Lesotho, Faculty of Humanities, Student Handbook (2008/2009), pp. 203213.

[23] Musa W. Dube, HIV/AIDS and the Curriculum: Methods of Integrating HIV/AIDS in Theological Programmes, Geneva, WCC, 2003; also of great relevance is an earlier text: NA, HIV \& AIDS Curriculum for Theological Institutions in Africa, Geneva, WCC, 2001.

[24] Prof. Chris U. Manus, Designer of the Proposal for the Creation of a New Department of Religions ... in the Faculty of Arts, University of Benin, Benin City, Nigeria, 2013, pp. 2 - 5.

[25] Ibid.,

[26] Gerrie ter Haar, 2008: in Ghana Bulletin of Theology, No.5, Vol 3, p. 2. 